\title{
First record of two genera of sea anemones (Cnidaria: Actiniaria), Octineon and Edwardsiella, from the North Pacific Ocean
}

\author{
N.P. Sanamyan ${ }^{1}$, K.E. Sanamyan ${ }^{1}$, N. McDaniel ${ }^{2}$, E.S. Bocharova ${ }^{3}$ \\ ${ }^{1}$ Kamchatka Branch of Pacific Geographical Institute, Far-Eastern Branch of the Russian Academy \\ of Sciences, Partizanskaya 6, Petropavlovsk-Kamchatsky, 683000, Russia. E-mail: \\ actiniaria@sanamyan.com \\ ${ }^{2}$ Vancouver, British Columbia, Canada.E-mail: neil.mcd@telus.net \\ ${ }^{3}$ Russian Federal Research Institute of Fisheries and Oceanography (VNIRO), Verkhnaya Kras- \\ noselskaya 17, Moscow, 107140, Russia.E-mail: bocharova.ekaterina@gmail.com
}

ABSTRACT: Two small sea anemones, Octineon suecicum and Edwardsiella loveni, known previously only from scarce records in European waters, are reported from British Columbia, Canada. Both genera, Octineon and Edwardsiella were not previously reported from the North Pacific. It is speculated that both species have a wider distribution than it appears from scarce existing records, but due to specific habitat and being flat and firmly attached to bedrock (Octineon) or inhabiting deep narrow crevices in bedrock (Edwardsiella) they escape traditional collecting devices such as trawls or dredges. The phylogenetic and statistical analyses showed that the family Octineonidae is probably related with Hormathiidae.

How to cite this article: Sanamyan N.P., Sanamyan K.E., McDaniel N., Bocharova E.S. 2018. First record of two genera of sea anemones (Cnidaria: Actiniaria), Octineon and Edwardsiella, from the North Pacific Ocean // Invert. Zool. Vol.15. No.1. P. 1-18. doi: 10.15298/invertzool.15.1.01

KEY WORDS: Sea anemone, Actiniaria, British Columbia, Octineon, Edwardsiella.

\section{Первая находка двух родов морских анемон (Cnidaria: Actiniaria), Octineon и Edwardsiella, в северной части Тихого океана}

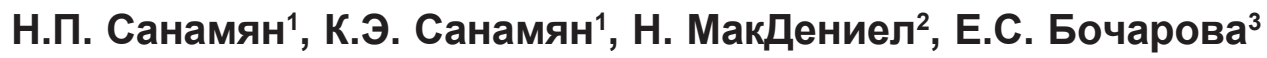 \\ ${ }^{1}$ Камчатский филиал Тихоокеанского института географии ДВО РАН, ул. Партизанская, \\ 6, Петропавловск-Камчатский 683000, Россия. E-mail: actiniaria@sanamyan.com \\ ${ }^{2}$ Ванкувер, Британская Колумбия, Канада. E-mail: neil.mcd@telus.net \\ ${ }^{3}$ Всероссийский научно-исследовательский институт рыбного хозяйства и океанографии \\ (ВНИРО), ул. Верхняя Красносельская, 17, Москва,107140, Россия. E-mail: bocharova. \\ ekaterina@gmail.com
}

РЕЗЮМЕ: Два вида актиний, Octineon suecicum и Edwardsiella loveni, известные ранее только по редким находкам в европейских морях, найдены в водах Британской Колумбии, Канада. Оба рода, Octineon и Edwardsiella не были ранее известны в северной части Тихого океана. Предполагается, что оба вида могут иметь более 
широкое распространение, чем известно по литературе, но из-за специфики местообитания, плоские и прочно прикрепленные к подводным скалам (Octineon) или населяющие узкие глубокие трещины в скалах (Edwardsiella), эти актинии не попадают в традиционные орудия лова, такие как тралы или драги. Филогенетический и статистический анализы показали, что семейство Octineonidae, по-видимому, близко к Hormathiidae.

Как цитировать эту статью: Sanamyan N.P., Sanamyan K.E., McDaniel N., Bocharova E.S. 2018. First record of two genera of sea anemones (Cnidaria: Actiniaria), Octineon and Edwardsiella, from the North Pacific Ocean // Invert. Zool. Vol.15. No.1. P. 1-18. doi: 10.15298/invertzool.15.1.01

КЛЮЧЕВЫЕ СЛОВА: Морские анемоны, Actiniaria, Британская Колумбия, Octineon, Edwardsiella.

\section{Introduction}

In our previous paper (Sanamyan et al., 2013) we stated that sea anemones of British Columbia appear to be more diverse than was thought previously. Numerous underwater photographs taken by one of us (N. McDaniel) show sea anemones that cannot always be assigned to species known for this region. In the present paper we report two anemones new for the region, Octineon suecicum Carlgren, 1940 and Edwardsiella loveni (Carlgren, 1892). These species share similar habitat: both are found at moderate depth and are firmly attached to bedrock or inhabit crevices in bedrock. Such species are very difficult to collect by traditional devices (trawls, dredges) and being small and inconspicuous they escape attention of most divers. It is interesting that both species were described originally from about the same locality in Europe: Sweden, Bohuslän, Väderöar, either in vicinity of the Lophelia-reef (O. suecicum) or on dead Lophelia (E. loveni). Octineon suecicum has not been reported since its original description (Carlgren, 1940). Edwardsiella loveni was reported from several neighboring European localities (Norway), but not from the wide area separating these European localities from British Columbia. The current record of Octineon is the first of a member of the family Octineonidae in North Pacific and is especially interesting because it allowed clarification of its taxonomic affinity: molecular data suggested that it may be related to Hormathiidae.

\section{Material and methods}

Specimens of Octineon suecicum and Edwardsiella loveni were observed and photographed underwater in their natural habitat to record colour, external appearance and position on substrate. Collected specimens were fixed in seawater formalin for morphology and in $90 \%$ ethanol for molecular study. The histological sections were prepared using isopropanol-mineral oil method (see Sanamyan, Sanamyan, 2012). Size ranges of cnidae were measured on small pieces of macerated tissue and the details of distribution of cnidae in different tissues were studied on histological sections stained by basic dyes (the method is described by Sanamyan et al., 2013). Cnidae terminology follows Weill (1934a, b) and Carlgren (1949), but classification of p-mastigophores follows Schmidt $(1969,1972,1974)$ with the modification of den Hartog (1995), for details see Sanamyan et al. (2012). The specimens are stored in Kamchatka Branch of Pacific Geographical Institute (KBPGI). Type material of Octineon suecicum was loaned from Swedish Museum of Natural History (SMNH).

\section{Molecular techniques}

DATA COLLECTION. The total DNA was extracted using Wizard SV Genomic DNA Purification System (Promega) following the manufacturer's protocol. Mitochondrial gene fragments 12S rRNA, 16S rRNA and COIII were 
Table 1. Primers for $18 \mathrm{~S}$ rRNA and 28S rRNA nuclear DNA fragment amplification. Таблица 1. Праймеры для амплификации фрагментов $18 \mathrm{~S}$ pPHК и $28 \mathrm{~S}$ рРНК ядерной ДНК.

\begin{tabular}{lll}
\hline Fragment & Primer name & Primer sequence (5'-3') \\
\hline 18S rRNA & Au_18S_F1 & ACATGCGAAAAGTCCCGACT \\
& Au_18S_R1 & TACTTCCCCCGGAACCCAAA \\
& $\mathrm{Au}$ _18S_F2 & AGGCCAGCGCTTGAATACAT \\
& $\mathrm{Au}$ 18S_R2 & CAACTTTTCGGCAGTCCACTG \\
28S rRNA & $\mathrm{Au} 28 \mathrm{~S}$-F & AATGAAGCGGGAACAGCTCA \\
& $\mathrm{Au} 28 \mathrm{~S} \_\mathrm{R}$ & GCGCTCTTACTCAAACCTTCC \\
\hline
\end{tabular}

amplified using published primers and protocols (Geller, Walton, 2001; Bocharova, 2015).

The nuclear gene fragments (18S rRNA and $28 \mathrm{~S}$ rRNA) were amplified with specially designed primers complementary to the Geneious 6.1.6 software (http://www.geneious.com) (Table 1). PCR cycling conditions were as follows: an initial denaturation for $2 \mathrm{~min}$ at $95^{\circ} \mathrm{C}$, followed by 35 cycles of denaturation for $30 \mathrm{~s}$ at $95^{\circ} \mathrm{C}$, annealing for $30 \mathrm{~s}$ at $55^{\circ} \mathrm{C}$ and extension for $1 \mathrm{~min}$ at $72^{\circ} \mathrm{C}$, and an additional extension for $5 \mathrm{~min}$ at $72^{\circ} \mathrm{C}$.

Sequence reaction was run using the BigDye v1.1 reagent kit (Applied Biosystems ${ }^{\odot}$ ). Purified and denatured reaction products were analyzed in the capillary molecular analyzer ABI PRISM3130 (Applied Biosystems ${ }^{\odot}$ ) using POP7 gel polymer. In order to treat the chromatograms, a Sequencing Analysis 3.7 (Applied Biosystems $^{\odot}$ ) and Geneious 6.1.6 were applied. After the treatment, the length of the $12 \mathrm{~S}$ rRNA fragments was 668 nucleotides, 16S rRNA -
479 nucleotides, COIII - 492 nucleotides, $18 \mathrm{~S}$ rRNA - 1493 nucleotides, 28S rRNA - 828 nucleotides. Forward and reverse sequences were assembled and compared (via BLAST) against the nucleotide database of GenBank to determine whether the target locus and organism were sequenced rather than a symbiont or other contaminant. All assembled sequences have been deposited in GenBank (Table 2).

DATA ANALYSIS. Sequences were manually edited and aligned using the Muscle algorithm with default parameters in Geneious 6.1.6. Complete and reduced alignments for each marker were analyzed separately and as a concatenated dataset (for Edwardsiidae) in MEGA 6.0 (Tamura et al., 2013). We conducted several analytical methods of phylogenetic reconstruction (Nei, Kumar, 2000). Phylogenetic analyses (Minimum Evolution (ME), Maximum Likelihood (ML), and Neighbor Joining (NJ)) were performed using the Tamura 3-parameter model in MEGA 6.0. The presented bootstrap values

Table 2. List of sea anemone species examined with GenBank accession numbers of their DNA sequences.

Таблица 2. Список исследованных видов актиний с номерами доступа в ГенБанке их последовательностей.

\begin{tabular}{|c|c|c|c|c|c|}
\hline \multirow{2}{*}{ Species } & \multicolumn{3}{|c|}{ Mitochondrial DNA } & \multicolumn{2}{c|}{ Nuclear DNA } \\
\cline { 2 - 6 } & 12S rRNA & 16S rRNA & COIII & 18S rRNA & 28S rRNA \\
\hline Edwardsiella loveni & KX946216 & KX946212 & KX946217 & KX946218 & KX946219 \\
\hline Octineon suecicum & - & KX946213 & - & - & - \\
\hline Spongiactis japonica & - & KX946214 & - & - & - \\
\hline Charisea saxicola & - & KX946215 & - & - & - \\
\hline
\end{tabular}


were calculated for (1) ME: rates among sites gamma distributed, No. of discrete gamma categories - 1, Close-Neighbor-Interchange heuristic method, Neighbor Joining initial tree, search level $-1,1000$ replicates. (2) ML: rates among sites - gamma distributed with invariant sites $(\mathrm{G}+\mathrm{I})$, No. of discrete gamma categories - 2, Nearest-Neighbor-Interchange heuristic method, NJ initial tree, very strong branch swap filter, 1000 replicates; (3) NJ: rates among sites - gamma distributed, No. of discrete gamma categories - 1,1000 replicates. Neighbor Joining algorithm was used to find the phylogram in Fig. 9.

Evolutionary analyses (pairwise distances between species and standard errors) were conducted using the Tamura-Nei model (Tamura, Nei, 1993) in MEGA 6.0. The rate variation among sites was modeled with a gamma distribution (shape parameter $=1$ ). Codon positions included were $1 \mathrm{st}+2 \mathrm{nd}+3 \mathrm{rd}+$ Noncoding. All positions containing gaps and missing data were eliminated.

\section{Taxonomy}

\author{
Order Actiniaria \\ Family Octineonidae Fowler, 1894 \\ Octineon Moseley in Fowler, 1894 \\ Octineon suecicum Carlgren, 1940 \\ Table 3; Figs. 1-5.
}

Octineon suecicum Carlgren, 1940: 59; 1942: 65; 1949: 38.

MATERIAL EXAMINED. KBPGI 473/1, Sakinaw Rock, Sechelt Inlet, British Columbia, Canada, $49^{\circ} 34.047^{\prime} \mathrm{N}, 123^{\circ} 48.151^{\prime} \mathrm{W}, 23 \mathrm{~m}$, granite bedrock, $\mathrm{t}=12.5^{\circ} \mathrm{C}, 14$ September 2015 , 12 specimens, collector Neil McDaniel; KBPGI 474/2, same locality, 30 m, 24 February 2016, 11 specimens, in formalin.

ADDITIONAL MATERIAL EXAMINED. SMNH 5633, syntypes of Octineon suecicum Carlgren, 1940 (Fig. 2B in the present paper).

DESCRIPTION. The specimens form compact, up to $20 \mathrm{~cm}$ diameter, clusters of numerous crowded individuals (more than 130 were counted on one underwater photograph). The pedal disc is broad, irregular in outline, flattened, strongly adhesive. Its diameter in large live specimens is about $10 \mathrm{~mm}$, the largest observed was about $12 \mathrm{~mm}$ in greatest dimension. The column in live fully expanded specimens is up to $10 \mathrm{~mm}$ in height, widely expanded proximally and becoming more or less cylindrical above where its diameter is about $2 \mathrm{~mm}$, divisible into scapus and scapulus (Fig. 1). The scapus is covered by brownish cuticle whose surface is almost free of foreign particles apart from occasional epibionts (mostly ciliophores Folliculina sp., seen as black dots in Fig. 2A, or Bryozoa). Mesenterial insertions are apparent, especially at the edge of the flattened proximal part of the column (Fig. 1C, D). The scapulus is smooth, lacking cuticle, not coloured apart from a set of short longitudinal white stripes, usually grouped by three in six groups, about halfway between the oral disc and the scapus (Fig. 1B, D). Wider strip in the middle of each group corresponds to primary endocoels. The oral disc is small, circular and flat, of the same or a bit greater diameter as the scapulus. The oral disc is either colourless and translucent (Fig. 1B) or has patches of white pigment. The distribution of these white patches on the oral disc is the same on all individuals of the same cluster. For example, in all specimens of the cluster shown on Fig. 1A, C, D the ventral third of the oral disc (the area between ventrolateral pairs of the mesenteries of the first cycle, including these pairs themselves) is white, while the remaining two-thirds of the disc is translucent with thin white lines along insertion of the mesenteries between the bases of the tentacles. These white lines and white colour of the oral disc may continue on the distal part of the scapulus (Fig. 1D). The tentacles are elongate and slender, up to $11 \mathrm{~mm}$ in large specimens and about $0.4 \mathrm{~mm}$ in diameter at their base, tapering distally, translucent. The tentacles are arranged hexamerously in three cycles on the outer part of the oral disc, usually up to 24 in number, but occasionally up to 30 due to the duplications sometimes occurring in the second cycle.

Preserved specimens are much flattened with short elevated central part, the largest specimen is about $10 \mathrm{~mm}$ in diameter and $5 \mathrm{~mm}$ in height. 
Table 3. Size ranges (length $\times$ width, in microns) and distribution of cnidae of Octineon suecicum. Letters in brackets correspond to letters in Fig. 5.

Таблица 3. Размеры (длина $\times$ ширина, в микронах) и распределение стрекательных капсул Octineon suecicum. Буквы в скобках соответствуют буквам на рис. 5.

\begin{tabular}{|c|c|c|c|}
\hline Body region & Cnidae & $\begin{array}{l}\text { Specimens from } \\
\text { British Columbia }\end{array}$ & $\begin{array}{l}\text { Syntypes } \\
\text { (SMNH 5633) }\end{array}$ \\
\hline Base & (A) basitrichs (common) & $13-17 \times 3-4$ & $10-15 \times 2.5-3.5$ \\
\hline \multirow[t]{4}{*}{ Scapus } & (B) basitrichs (few) & $6-10 \times 1-2$ & $6-10 \times 1-2$ \\
\hline & (C) basitrichs (common) & $12-17 \times 3-4.5$ & $10-16 \times 2.5-3$ \\
\hline & (D) holotrichs (common) & $8-11 \times 2-3$ & $8-9 \times 2-2.5$ \\
\hline & (E) p-mastigophores B (few) & $25-37 \times 2.5-3$ & $24-29 \times 3$ \\
\hline Scapulus & (F) basitrichs (numerous) & $16-21 \times 3-3.5$ & - \\
\hline \multirow[t]{5}{*}{ Tentacles } & $\begin{array}{l}\text { (G) robust spirocysts } \\
\text { (numerous) }\end{array}$ & $15-30 \times 3-5.5$ & $15-25 \times 4-5$ \\
\hline & $\begin{array}{l}\text { (H) gracile spirocysts } \\
\text { (numerous) }\end{array}$ & $13-26 \times 2.5-4$ & $13-21 \times 2.5-3$ \\
\hline & (I) basitrichs (rare) & $7-10 \times 1.5-2$ & - \\
\hline & (J) basitrichs (common) & $18-25 \times 2-3$ & $18-19 \times 2$ \\
\hline & (K) p-mastigophores B1 (rare) & $13-21 \times 3-4$ & - \\
\hline \multirow[t]{4}{*}{ Actinopharynx } & (L) basitrichs (rare) & $8-12 \times 1.5-2$ & $8-12 \times 1.5$ \\
\hline & (M) basitrichs (common) & $21-27 \times 2-3$ & $19-26 \times 2-3$ \\
\hline & (N) p-mastigophores A (few) & $17-24 \times 3-4.5$ & $20 \times 4$ \\
\hline & $\begin{array}{l}\text { (O) p-mastigophores B1 } \\
\text { (numerous) }\end{array}$ & $12-15 \times 2.5-3.5$ & $12-13 \times 2.5-4$ \\
\hline \multirow[t]{4}{*}{ Filaments } & (P) basitrichs (common) & $8-13 \times 1.5-2$ & $8-12 \times 1.5-2$ \\
\hline & (Q) basitrichs (few) & $19-26 \times 2-3.5$ & $20-26 \times 2-2.5$ \\
\hline & (R) p-mastigophores A (few) & $19-26 \times 3-4.5$ & $20 \times 4$ \\
\hline & $\begin{array}{l}\text { (S) p-mastigophores B1 } \\
\text { (numerous) }\end{array}$ & $12-23 \times 2.5-4$ & $11-13(18) \times 3-4$ \\
\hline \multirow[t]{3}{*}{ Acontia } & (T) basitrichs (few) & $8-12 \times 1.5-2$ & - \\
\hline & (U) basitrichs (rare) & $15-20 \times 1.5-2$ & $14-20 \times 1.5-2$ \\
\hline & (V) basitrichs (numerous) & $50-60 \times 5-6$ & $48-59 \times 5-6$ \\
\hline Endoderm & basitrichs (rare) & $7-13 \times 1-2$ & $7-9 \times 2$ \\
\hline
\end{tabular}

The tentacles and scapulus are not visible (Fig. 2A). The tentacles are capable of invagination. The ectoderm on the scapus beneath the cuticle is very thin, in some places no more that $1 \mu \mathrm{m}$ thick, but occasionally up to $10 \mu \mathrm{m}$ and more, especially in the folds. The ectoderm of the scapulus is much thicker, 19-35 $\mu \mathrm{m}$ (Fig. 2C). The mesogloea of the scapus and scapulus is up to $300 \mu \mathrm{m}$ in thickness, but much thinner on the base. Mesogloea of the invaginated part of scapus and scapulus forms six prominent ridges (Fig. 2D). The cuticle covering the scapus is thin
(3-5 $\mu \mathrm{m})$, not stratified, attached to column on areas with modified ectoderm with mesogloeal strands reaching the cuticle (as in tenaculi, Fig. $2 \mathrm{E}$ ). At the base cuticle is attached by large crowded mesogloeal strands distributed along the whole base (Fig. 3F). Endoderm contains numerous gland cells which may form almost continuous layer(Fig. 3F). The marginal sphincter is mesogloeal, alveolar, not strong, rather long (up to $2.5 \mathrm{~mm}$ ), situated in the scapulus and continues proximally up to the middle part of the scapus, where it lies closer to endoderm. The 

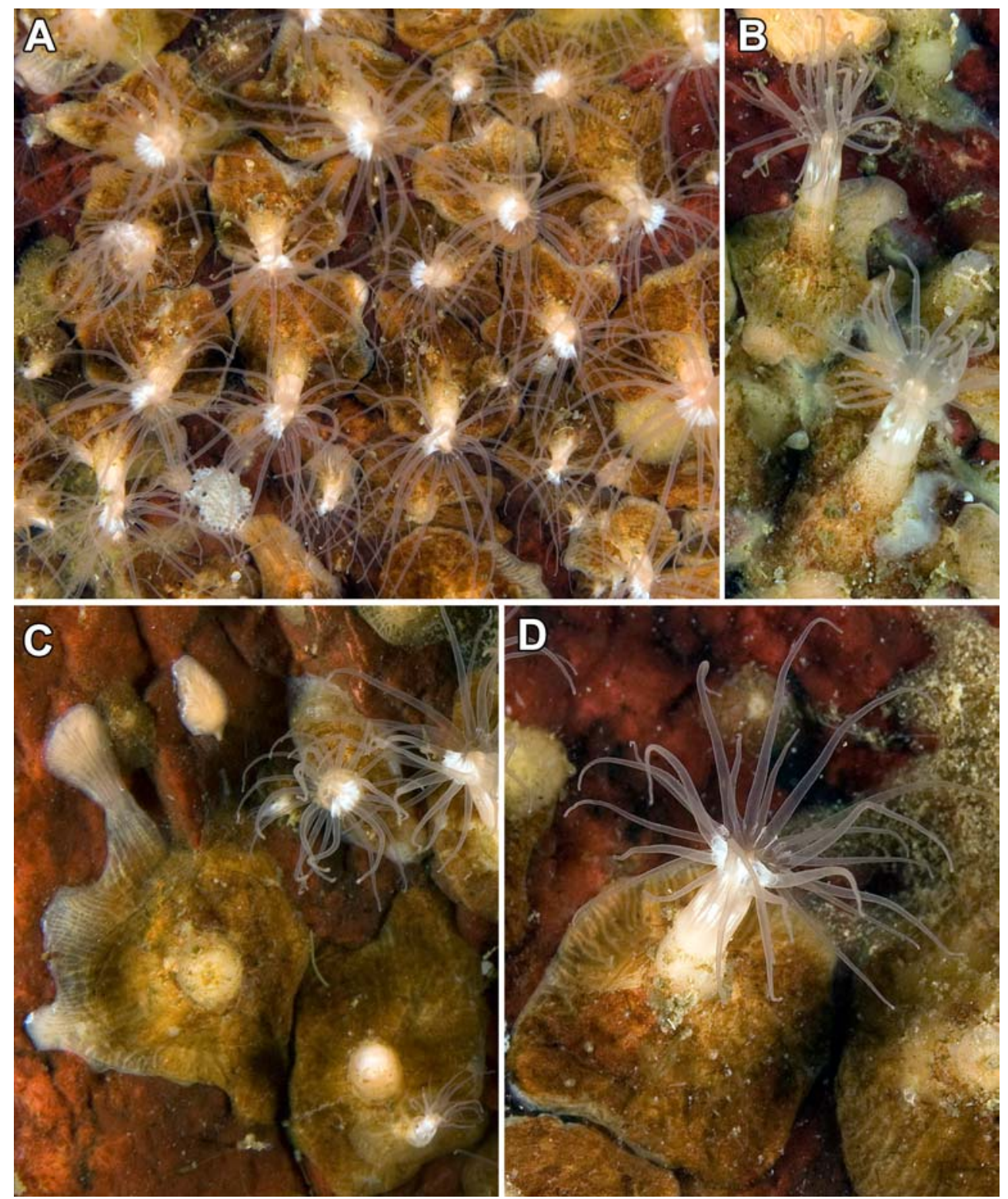

Fig. 1. Octineon suecicum Carlgren, 1940. A-D - live specimens in natural habitat.

Рис. 1. Octineon suecicum Carlgren, 1940. A-D - живые экземпляры в естественной среде обитания.

sphincter is separated from endodermal circular muscles of column and from ectoderm by a layer of mesogloea. On transverse section of the sphincter the individual muscle meshes are rather sparse and lie mostly in the middle layer of the mesogloea (Fig. 2C). Radial muscles of the oral disc and longitudinal muscles of the tentacles are ectodermal (Fig. 2F).

The actinopharynx has no distinguishable siphonoglyphs. Because the preserved specimens were strongly flattened and contracted it was not possible to obtain perfect transverse 

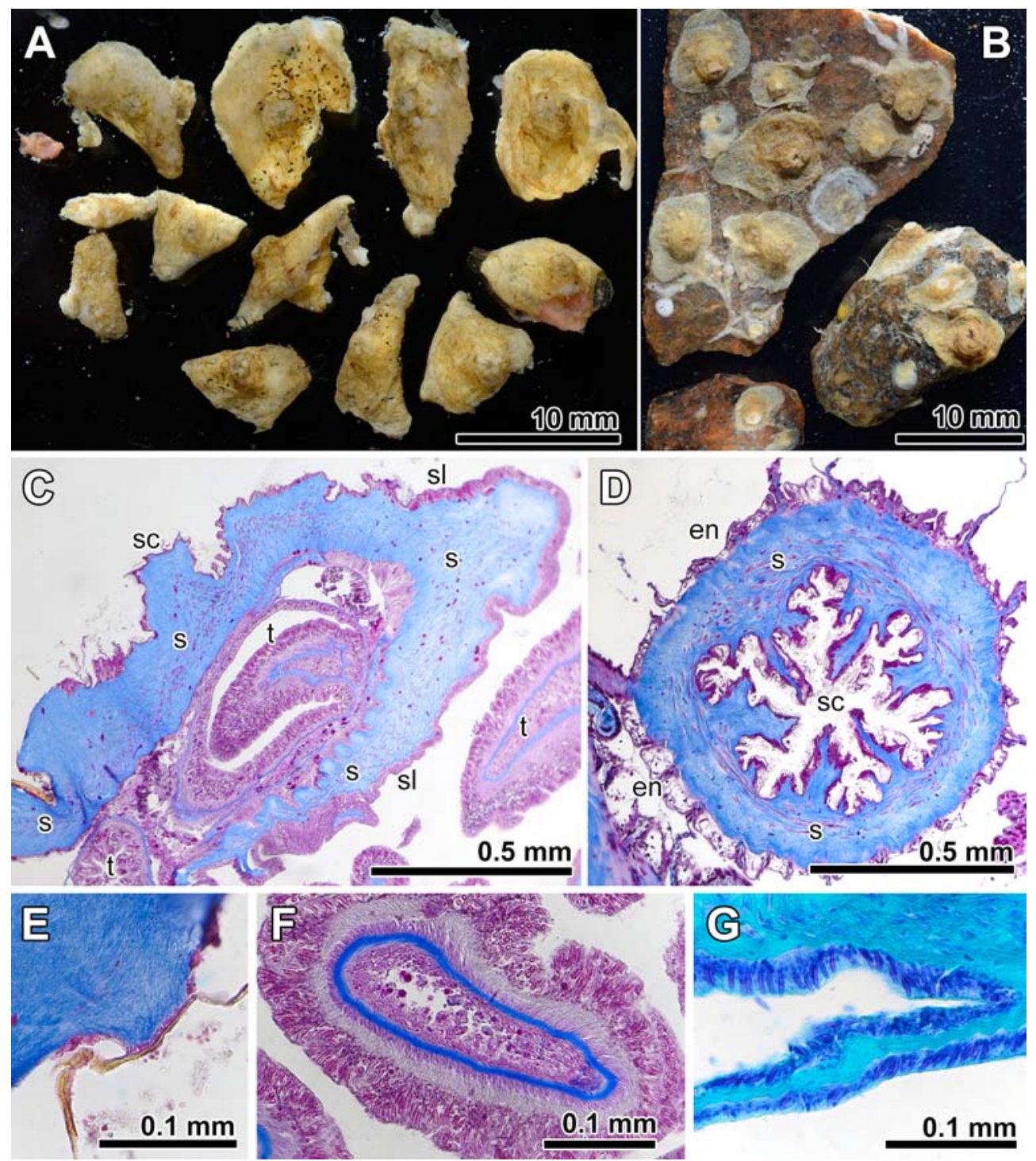

Fig. 2. Octineon suecicum Carlgren, 1940. A — specimens from British Columbia, preserved; B — syntypes SMNH 5633 (on stones); C - longitudinal section of the distal part of the scapus and scapulus; D transverse section of introverted part of the scapus; E - tenacula; F - transverse section of the tentacle; $\mathrm{G}$ - crowded basitrichs in the ectoderm of the scapulus.

Abbreviations: en - endoderm; $\mathrm{s}$ - sphincter; $\mathrm{sc}$ - scapus; $\mathrm{sl}$ - scapulus; $\mathrm{t}$ - tentacle.

Рис. 2. Octineon suecicum Carlgren, 1940. А - фиксированные экземпляры из Британской Колумбии; B - синтипы SMNH 5633 (на камнях); C - продольный срез через дистальную часть скапуса и скапулюс; D - поперечный срез через ввернутую часть скапуса; E — тенакуля; F — поперечный срез через щупальце; $\mathrm{G}$ - многочисленные базитрихи в эктодерме скапулюса.

Обозначения: en - энтодерма; s - сфинктер; sc - скапус; sl - скапулюс; $\mathrm{t}$ - щупальце. 

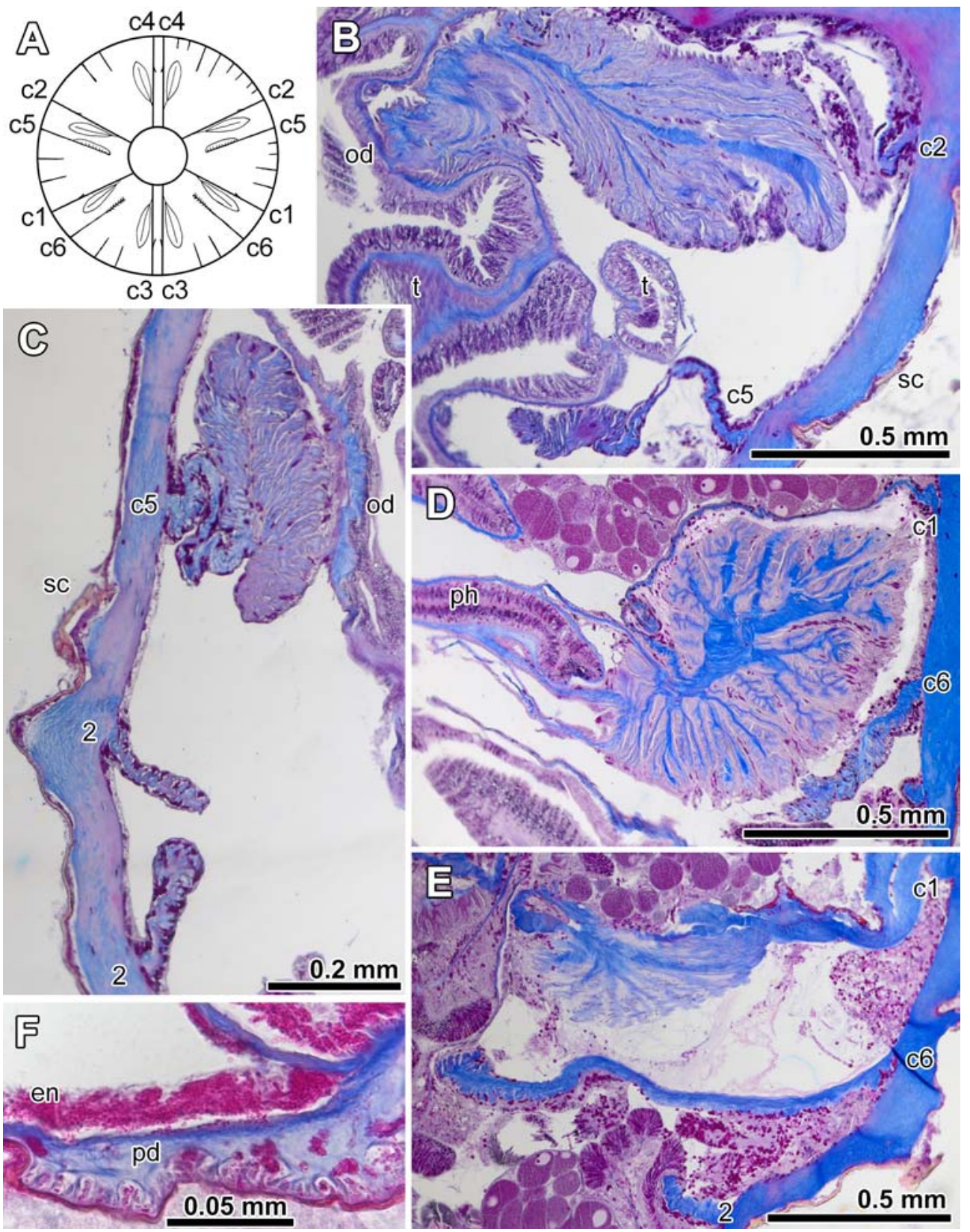

Fig. 3. Octineon suecicum Carlgren, 1940. A — arrangement of the mesenteries; B - transverse sections through dorso-lateral pair of the mesenteries of the first cycle; $\mathrm{C}$ - transverse section of the microcnemes (2 - mesenteries of the second cycle); D - transverse sections through ventro-lateral pair of the mesenteries of the first cycle on the level of the actinopharynx; E - the same mesenteries below actinopharynx; F section through the pedal disc.

Abbreviations: $\mathrm{c} 1-\mathrm{c} 6$ - couples of the mesenteries; en - endoderm; od — oral disc; pd — pedal disc; sc — scapus; $\mathrm{t}$ - tentacle.

Рис. 3. Octineon suecicum Carlgren, 1940. А - схема организации мезентериев; В - поперечный срез через дорсо-латеральную пару мезентериев первого цикла; C - поперечный срез через микро- 

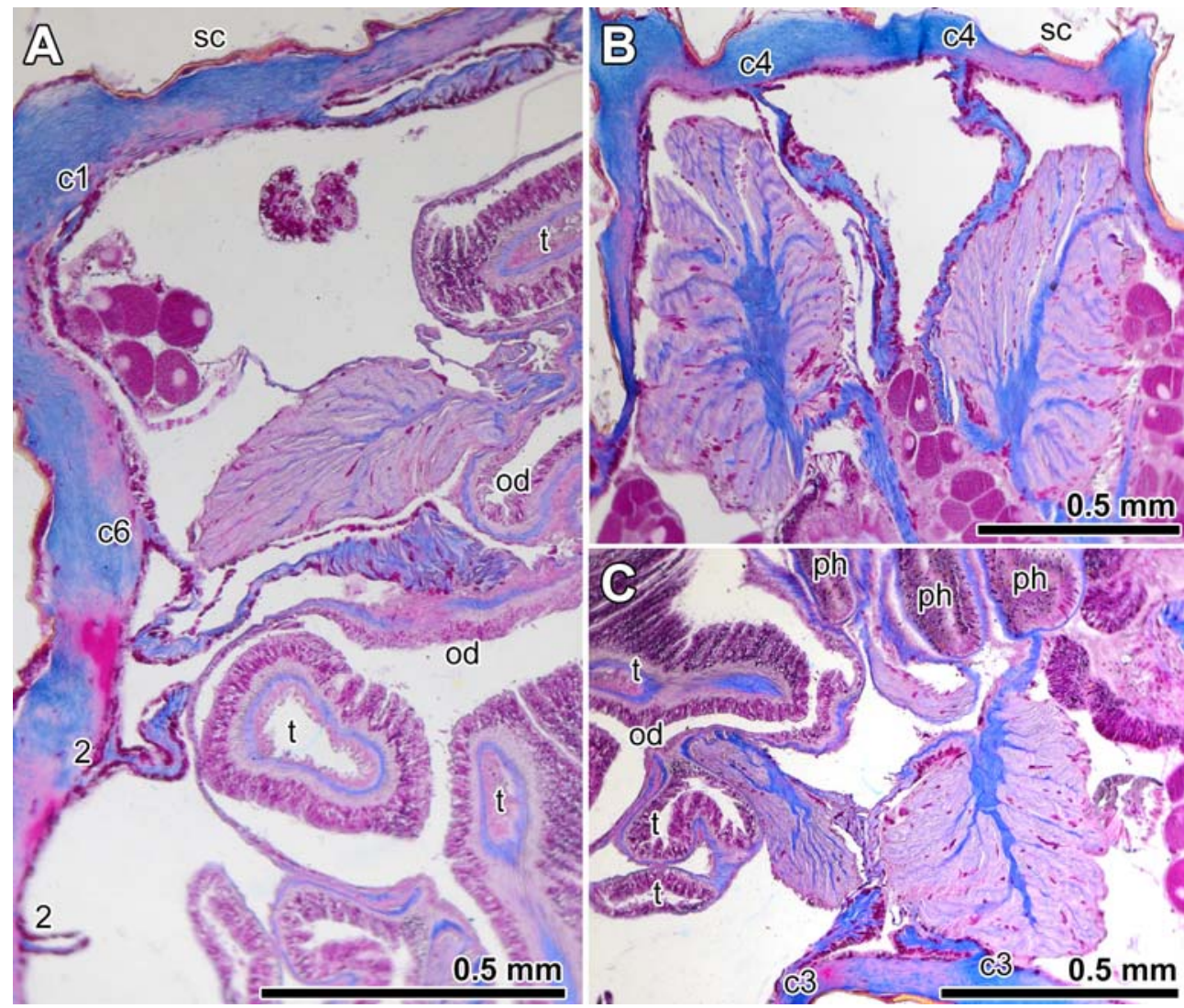

Fig. 4. Octineon suecicum Carlgren, 1940. A - transverse section through the distal part of column (2 mesenteries of the second cycle); B - transverse sections through dorsal pair of the directives; $\mathrm{C}$ transverse sections through ventral pair of the directives.

Abbreviations: $\mathrm{c} 1-\mathrm{c} 6$ - couples of the mesenteries; od - oral disc; ph - actinopharynx; sc - scapus; $\mathrm{t}$ - tentacle. Рис. 4. Octineon suecicum Carlgren, 1940. А - поперечный срез через дистальную часть колюмна (2 мезентерии второго цикла); В - поперечный срез через дорсальную пару направляющих мезентериев; C - поперечный срез через вентральную пару направляющих мезентериев.

Обозначения: c1-c6 — билатеральные пары мезентериев; od — оральный диск; $\mathrm{ph}$ - глотка; $\mathrm{sc}$ — скапус; $\mathrm{t}$ щупальце.

sections of mesenteries to illustrate their distribution and shape. As it appears on underwater photographs the first and the second cycles of mesenteries reach the oral disc and the number of mesenteries at the limbus may be about 100, i.e. at least five cycles and some mesenteries of sixth cycle present at the limbus. Schematic arrangement of the mesenteries is shown in Fig. $3 \mathrm{~A}$. Eight mesenteries of the first cycle, arranged as in Edwardsia, are macrocnemes. They are perfect and have retractors, filaments, gonads and acontia. The retractor muscles are strong, circumscribed, pinnate with well developed central mesogloeal lamella. Free ends of

мезентерии (2 - мезентерии второго цикла); D — поперечный срез через вентро-латеральную пару мезентериев первого цикла на уровне глотки; E — те же мезентерии ниже уровня глотки; F — cрез через педальный диск.

Обозначения: c1-c6 - билатеральные пары мезентериев; en — энтодерма; od — оральный диск; рd — педальный диск; sc - скапус; $\mathrm{t}$ - щупальце. 


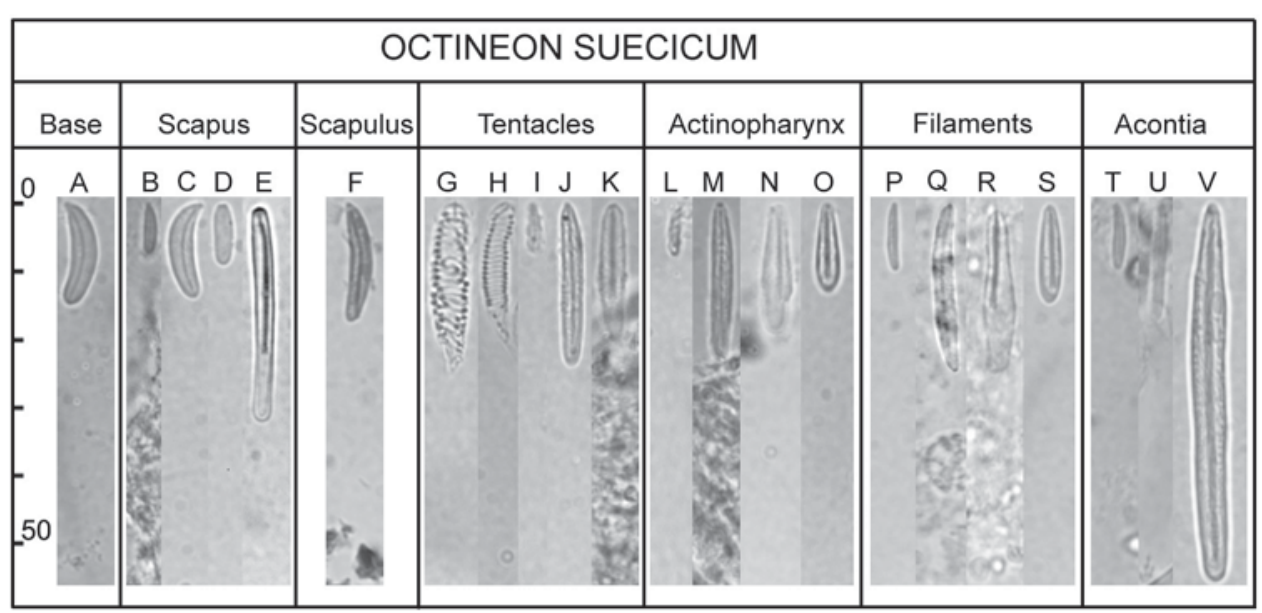

Fig. 5. Octineon suecicum Carlgren, 1940, distribution of cnidae (see Table 3 for size ranges).

Рис. 5. Octineon suecicum Carlgren, 1940, распределение книд (размеры указаны в табл. 3).

their pennons are always directed to the body wall (Figs. 3B, D; 4A-C). On the opposite side the parietobasilar muscles are present; they may form a short free flap (up to $100 \mu \mathrm{m}$ in length). Parietal muscles are not developed. The mesenteries of fifth couple (paired with dorso-lateral macrocnemes) are microcnemes but have diffuse muscles at their inner (closer to actinopharynx) parts which on some sections resemble diffuse retractors (Fig. 3B, C). The mesenteries of the sixth couple (paired with ventro-lateral macrocnemes) are similar to those of the fifth couple but have weaker muscles (Figs. 3D, E; 4A). Mesenteries of the second and subsequent cycles are weak, without recognizable muscles on the endocoelic sides, but with discernible muscles on the exocoelic sides corresponding to parietobasilar muscles (Fig. 3C). Basilar muscles indiscernible (Fig. 3F).

All studied specimens were female. The diameter of the ova is up to $200 \mu \mathrm{m}$. Many images show examples of ongoing pedal laceration (Fig. 1C). Most probably compact clusters of similarly coloured specimens are the result of asexual reproduction.

Cnidom includes robust and gracile spirocysts, basitrichs, holotrichs, p-mastigophores A, p-mastigophores B (see Table 3 and Fig. 5, cnidae of the column and tentacles were studied in seven specimens, those of the actinopharynx in four specimens, those of the filaments in 17 specimens, those of acontia in six specimens and those of the endoderm in two specimens; cnidae of the syntypes were studied in seven specimens). Numerous basitrichs in the scapulus (Fig. 5F) are larger than in scapus and form an almost solid layer (Fig. 2G). Large basitrichs of the tentacles (Fig. 5J) are concentrated at the tips.

HABITAT. The clusters of this species were found at a depth of 23 to $30 \mathrm{~m}$. They were concentrated on a steeply sloping bedrock bottom.

REMARKS. The genus Octineon is the sole member of the family Octineonidae and currently contains three species: O. lindahli (Carpenter in Carpenter et Jeffreys, 1871), O. suecicum and O. chilense Carlgren, 1959.

The type species of the genus, $O$. lindahli (=Ammodiscus lindahli Carpenter in Carpenter et Jeffreys, 1871), was dredged by H.M.S. "Porcupine" in 1870 off the south coast of Spain at depths from 413 to $702 \mathrm{~m}$. The morphology of these specimens was described in detail by Fowler (1894) and Carlgren (1921, 1931). The information provided by Fowler (1894: 461) suggests that the specimens were rather numerous in that location ("obtained $\langle\ldots\rangle$ a large collection of thin sand discs...") but surprisingly the species has not been recorded again during 
the past 150 years. Octineon lindahli lives unattached on the sea floor, has a thin disk-shaped body densely covered by attached sand and has only 12 tentacles.

The second species, O. suecicum, is also based on a single lot of specimens. In his brief original description Carlgren (1940: 60) gives the locality as "Sweden, Bohuslän. Väderöar, in vicinity of the Lophelia-reef, 60-70 m on small stones or shells". A more detailed description provided by Carlgren (1942) is based on the same material. The species lives attached to hard objects, its body is free from sand and it has at least 24 tentacles in fully developed specimens, so it differs quite distinctly from $O$. lindahli and cannot be confused with it.

The third species, $O$. chilense is known only from the original description based on specimens from two stations from the region of Los Lagos, Chile, from $100 \mathrm{~m}$ and 50-60 m depth. This species is very similar to O. suecicum. Carlgren (1959) says it has a stronger sphincter muscle and stronger retractor. In our opinion the more significant difference is the larger size of basitrichs in acontia $(62-70.5 \times 5.6 \mu \mathrm{m})$.

The present record of a member of the genus Octineon from British Columbia is a first record for a half century since Octineon was last recorded. This record is geographically distant from all previously known locations (Spain, Norway and Chile). The morphology of specimens described herein corresponds closely to that of $O$. suecicum in most details, including the coloration of living specimens, e.g. probably characteristic for the species and rather distinctive arrangement of short longitudinal white lines grouped by three on the scapulus (see Fig. 1B, D), Carlgren (1940: 59) describes them as "on the lowest part of the scapulus 3 opaque white, longitudinal lines, sometimes more irregularly arranged". We examined nematocysts of syntypes of $O$. suecicum (SMNH 5633). Their size ranges and composition are similar to whose of the specimens from British Columbia (see Table 3), especially the nematocyst of the scapus and base, available without dissection of the specimens, which were studied on more specimens.
Family Edwardsiidae Andres, 1881

Edwardsiella Andres, 1883

Edwardsiella loveni (Carlgren, 1892)

Table 4; Figs. 6-8.

Milneedwardsia loveni Carlgren, 1892: 456; 1893 : 17; 1921: 60 .

Fagesia loveni: Carlgren, 1940: 23.

MATERIAL EXAMINED. KBPGI 475/1, Howe Sound, British Columbia, Canada, $49^{\circ} 27.036^{\prime} \mathrm{N}, 123^{\circ} 14.494^{\prime} \mathrm{W}, 20 \mathrm{~m}$, protruding from crevices in bedrock vertical wall, 5 March 2016, 5 specimens, collector Alex English, in formalin; KBPGI 476/2, same locality, 13 December 2015, 7 specimens, collectors Alex English and Douglas Swanston, in 90\% ethanol.

DESCRIPTION. The specimens are attached to bedrock in very narrow crevices and cracks and, according to collectors' notes are extremely tiny, measuring only 5-7 $\mathrm{mm}$ tall. This, however, applies only to scapulus and a very distal part of the scapus while the remaining part of column is hidden in the crevices of bedrock and not visible from exterior (Fig. 6B, C). All collected specimens lack proximal parts of their bodies so the specimens were probably deeply inserted in the crevices and since the scapulus on preserved specimens constitutes only a small fraction of the body length the specimens actually should be significantly longer (Fig. 6A). The column of living specimens is approximately $1.5 \mathrm{~mm}$ in diameter. The diameter of tentacular crown is up to $10 \mathrm{~mm}$. The largest preserved specimen is $14 \mathrm{~mm}$ long (without proximal part of column), diameter of its column varies from $1 \mathrm{~mm}$ distally to $4 \mathrm{~mm}$ in most proximal part. The scapulus on preserved specimens is $0.7-2 \mathrm{~mm}$ in length. The scapus is covered by grayish-brown cuticle. The surface of the cuticle is clean, without attached sand grains and other foreign matter. The scapulus and the tentacles are not retracted and visible in all preserved specimens, although live the specimens are capable of retracting their tentacles completely (as seen in the specimen on top left corner of the Fig. 6C). The scapulus is naked, slightly and gradually tapering to the distal end. It has eight prominent longitudinal ridges which are present on the scapus too (at least on its 
Table 4. Size ranges (length $\times$ width, in microns) and distribution of cnidae of Edwardsiella loveni. Letters in brackets correspond to letters in Fig. 8 .

Таблица 4. Размеры (длина $\times$ ширина, в микронах) и распределение стрекательных капсул $E d-$ wardsiella loveni. Буквы в скобках соответствуют буквам на рис. 8.

\begin{tabular}{lll}
\hline Body region & Cnidae & Size ranges $(\mu \mathrm{m})$ \\
\hline Scapus & (A) basitrichs (few) & $8-11 \times 1-2$ \\
& (B) basitrichs (few) & $20-37 \times 5-7$ \\
Scapulus & (C) basitrichs (numerous) & $19-35 \times 5-6$ \\
Tentacles & (D) robust spirocysts (numerous) & $25-38 \times 5-6$ \\
& (E) gracile spirocysts (numerous) & $18-33 \times 2.5-5$ \\
& (F) heterotrichs (common) & $16-31 \times 3-5$ \\
& (G) basitrichs (common) & $16-30 \times 4-5.5$ \\
Actinopharynx & (H) basitrichs (few) & $13-18 \times 2-3$ \\
& (I) basitrichs (common) & $21-27 \times 2.5-4$ \\
Filaments & (J) p-mastigophores A (rare) & $20-23 \times 5-6$ \\
Endoderm & (K) p-mastigophores A (common) & $15-21(23) \times(3.5) 5-7$ \\
& basitrichs (rare) & $12-16 \times 3.5-5.5$ \\
\hline
\end{tabular}

distal part). Very short thin walled capitulum is discernible between the bases of the tentacles and the scapulus. The tentacles are slender, very gradually tapering to pointed tips, all of about the same length, up to $5 \mathrm{~mm}$ in living specimens. The number of the tentacles, as counted on underwater photographs in full-size specimens, varies from 22 to 42 ; one small specimen had 12 tentacles. The arrangement of the tentacles appears to be hexamerous, in up to four cycles. The oral disk is very small with prominent oral cone.

The overall colour of the distal part of the anemone, including the scapulus, tentacles and oral disc, is translucent beige or pale orange. Orange tint is darker on the actinopharynx visible though the translucent wall of the scapulus and the oral disc. Longitudinal whitish lines on the scapulus run along the crest of each scapular ridge.

Eight longitudinal columnar ridges are formed by thickened mesogloea (up to $90 \mu \mathrm{m}$ ) and ectoderm (up to $70 \mu \mathrm{m}$ on the crests of the ridges) between the insertions of macrocnemes. Between the ridges both mesogloea and ectoderm are thinner (10 and $20 \mu \mathrm{m}$ respectively). Columnar endoderm is thin $(10-15 \mu \mathrm{m})$ and of the same thickness beneath and between the ridges (Fig. 7A, C). Column has no nemathybomes and tenacules. The cuticle is thin and not stratified, covered by thin mucus-like layer, closely bearing against the ectoderm and fastened by numerous thin evenly distributed mesogloeal strands. Radial muscles of the oral disc and longitudinal muscles of the tentacles are ectodermal (Fig. 7 D). Actinopharynx has no discernible siphonoglyphs and has eight internal longitudinal ridges, formed by thickened ectoderm, corresponding to eight macrocnemes (Fig. 7 E). Mesogloea of the actinopharynx is thin. Eight macrocnemes, arranged as in $E d$ wardsia, are present along the whole length of the body and small microcnemes in the capitulum only (Fig. 7B), at the bases of the tentacles. Microcnemes of the first cycle (four microcnemes paired with lateral macrocnemes) in most distal part are attached to actinopharynx.

Retractor muscles are large, restricted, with large pennon, with about 20-30 muscle processes, some of which are branched. On transverse sections retractors are situated close to actinopharynx and attached to the body wall by long thin mesenterial lamella (Fig. 7A). Parietal muscles are well developed. On transverse sections of the scapulus they are circumscribed and form either a fan or a pennon on each side of the 

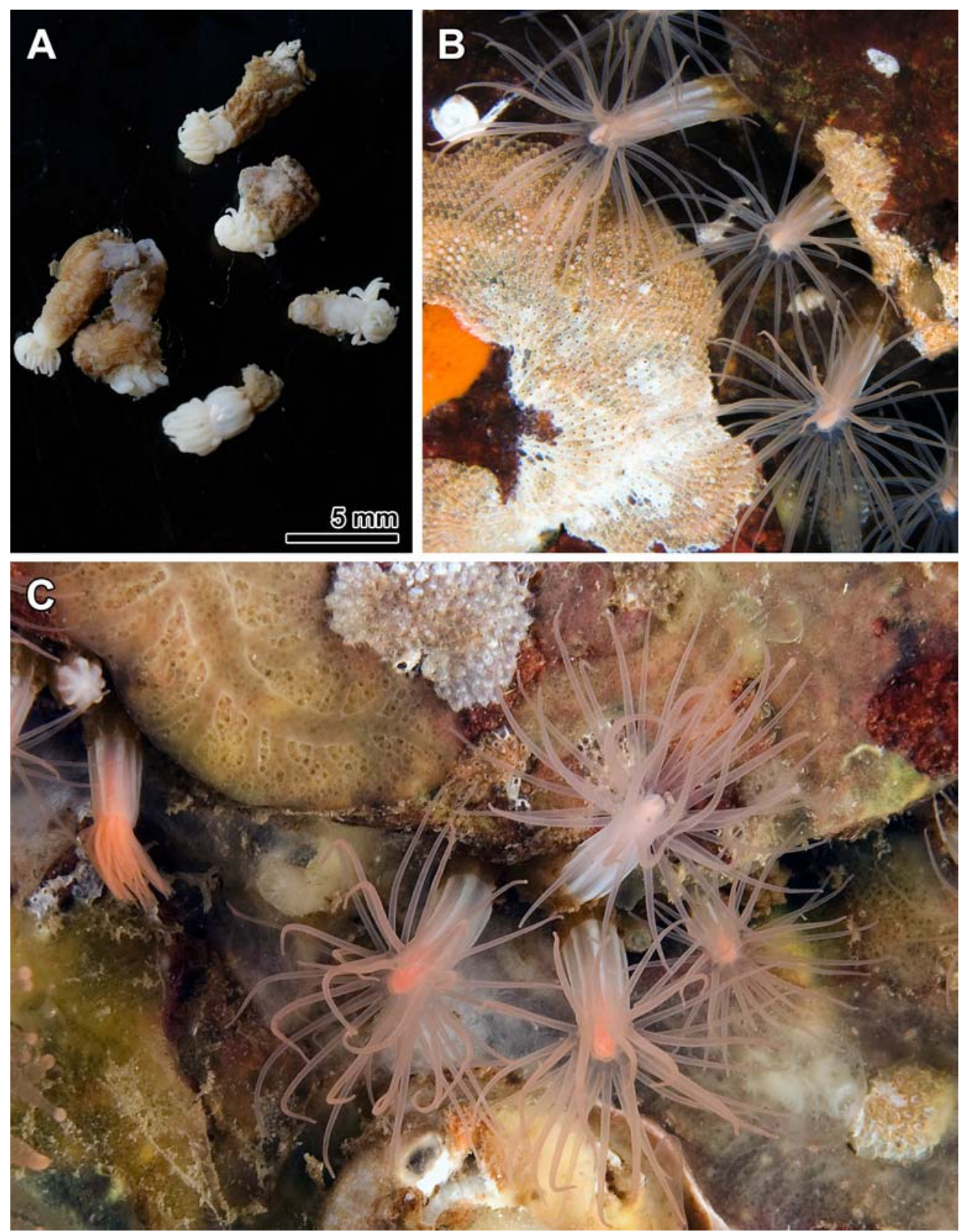

Fig. 6. Edwardsiella loveni (Carlgren, 1892). A - formalin preserved specimens; B-C - live specimens in natural habitat.

Рис. 6. Edwardsiella loveni (Carlgren, 1892). А - экземпляры, зафиксированные в формалине; В-C живые экземпляры в естественной среде обитания.

mesentery (Fig. 7A) but in the scapus they may be more diffuse, triangular or oval in outline (Fig. 7F).
Cnidom includes robust and gracile spirocysts, heterotrichs, basitrichs, p-mastigophores A (Table 4, Fig. 8, cnidae of the scapus, scapu- 


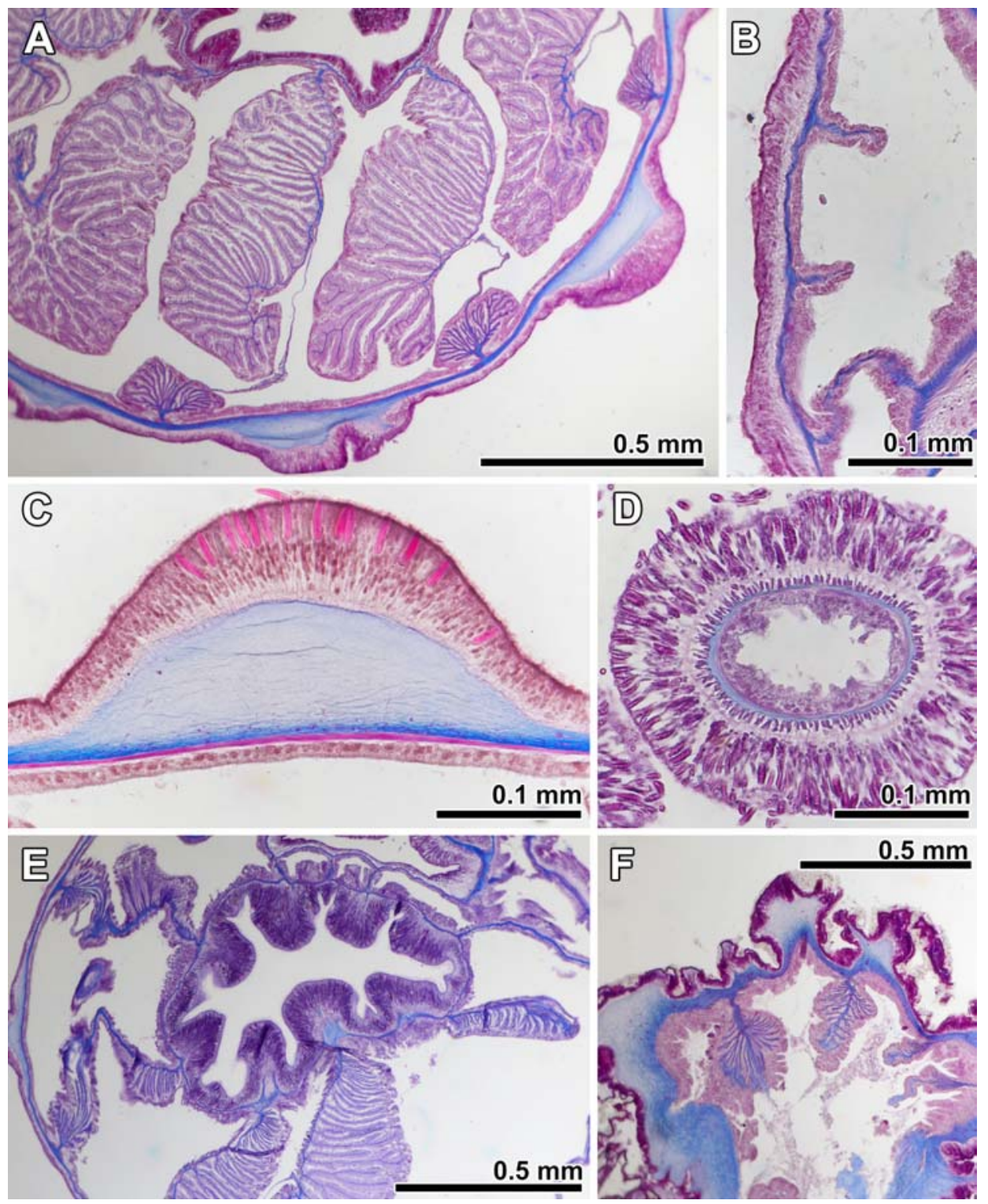

Fig. 7. Edwardsiella loveni (Carlgren, 1892). A - transverse section through the scapulus; B microcnemes of the second cycle in the capitulum; $\mathrm{C}$ - transverse section through the scapular ridge with nematocyst battery in ectoderm; D - transverse section through the tentacle; $\mathrm{E}$ - transverse section of column on the level of the actinopharynx; F - transverse section through the scapus below the actinopharynx. Рис. 7. Edwardsiella loveni (Carlgren, 1892). А - поперечный срез через скапулюс; В - микромезентерии второго цикла в капитулюме; C - поперечный срез через скапулярный гребень с батареей нематоцист в эктодерме; D - поперечный срез через щупальце; $\mathrm{E}$ - поперечный срез через колюмн на уровне глотки; F - поперечный срез через скапус ниже глотки.

lus and tentacles were studied in three specimens, those of the actinopharynx in two specimens, those of the filaments and endoderm in one specimen). Basitrichs on the scapulus are concentrated along the crests of the scapular ridges forming a kind of nematocyst battery 


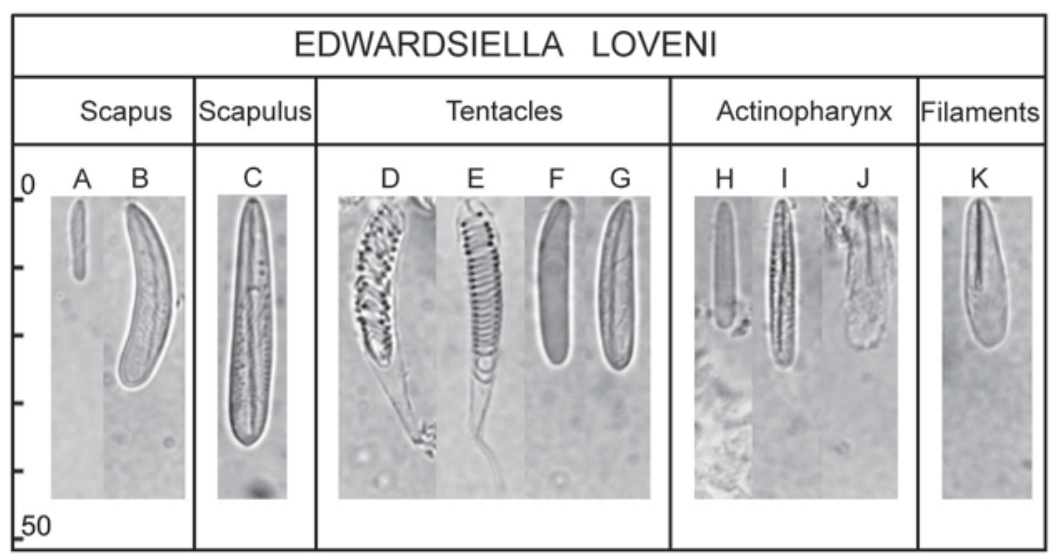

Fig. 8. Edwardsiella loveni (Carlgren, 1892), distribution of cnidae (see Table 4 for size ranges). Рис. 8. Edwardsiella loveni (Carlgren, 1892), распределение книд (размеры указаны в табл. 4).

(Fig. 7C). Large thick basitrichs of the column and tentacles are often somewhat curved. We identify the capsule from the tentacles depicted on Fig. 8F as heterotrich since basal part of the tubule in unfired capsule looks like a stick (5-8 $\mu \mathrm{m}$ long) that suggests that either basal part of the tubule is larger in diameter than the rest of the tubule, or it has longer barbs. This capsule probably has no apical flap and is not stained by basal dyes as basitrichs.

HABITAT. All recorded specimens were attached to bedrock in narrow crevices, not covered by sand at a depth of about $20 \mathrm{~m}$.

REMARKS. The genus Edwardsiella comprises four valid species, none of which was known previously from the North Pacific.

Edwardsiella loveni was known previously from original and subsequent descriptions by Carlgren $(1892,1893,1921)$ based on several lots of specimens dredged from depths of 90 to $640 \mathrm{~m}$ in waters around Sweden and Norway. Unlike many members of Edwardsiidae the specimens do not live buried in sediment but are anchored in crevices of solid objects such as dead calyces of Lophelia, dead Paragorgia or other octocorals (Carlgren, 1921). Despite the large geographic distance between our specimens from British Columbia and previously known locations, all features of our specimens correspond well to detailed descriptions provided by Carlgren $(1892,1893,1921)$ and we iden- tify them as E. loveni. That constitutes the first record of the species and genus in the North Pacific. Most probably E. loveni, and other Edwardsiella species, have much wider distribution than might be inferred from existing records, but the specimens inhabiting crevices in bedrock cannot be caught by trawls or dredges.

Other Edwardsiella species include:

Edwardsiella carnea (Gosse, 1856) is known from many records from European seas. It typically has fewer tentacles than E. loveni, and its retractor muscles on cross sections are much weaker and have fewer muscle processes (Carlgren, 1921). The colour, with its "deep orange" (Manuel, 1988: 196) or "scarlet-red" (Carlgren, 1921: 62) actinopharynx and inner part of the oral disc also may be characteristic.

Edwardsiella ignota (Carlgren, 1959) is known only from original description from Peru (Carlgren, 1959). Fautin (2016) lists it among valid species but states it is "nomen dubium according to Williams, 1981", however there is no such statement in the paper of Williams (1981). Original description of E. ignota is detailed enough and accompanied by figures; it cannot be regarded as nomen dubium. According to Carlgren (1959) it has 20 or possibly 24 tentacles, i.e. the species has significantly fewer tentacles than all other Edwardsiella species.

Edwardsiella lineata(Verrill, 1873), known only from Atlantic coast of North America, was 
Table 5. Estimates of evolutionary divergence between concatenated fragments (12S rRNA, 16S rRNA, COIII, 18S rRNA, 28S rRNA) of Edwardsia elegans, E. japonica, E. timida, Edwardsiella loveni, and Nematostella vectensis in family Edwardsiidae. Таблица 5. Значения эволюционной дивергенции между объединенными фрагментами $(12 \mathrm{~S}$ pРHK, 16S pPHК, COIII, 18S pPHК, 28S pPHK) у Edwardsia elegans, E. japonica, E. timida, Edwardsiella loveni и Nematostella vectensis в семействе Edwardsiidae.

\begin{tabular}{l|ccccc}
\hline Species & E. elegans & E. japonica & E. timida & E. loveni & N. vectensis \\
\hline Edwardsia elegans & & 0,003 & 0,003 & 0,004 & 0,004 \\
Edwardsia japonica & 0,041 & & 0,004 & 0,004 & 0,005 \\
Edwardsia timida & 0,035 & 0,041 & & 0,004 & 0,004 \\
Edwardsiella loveni & 0,040 & 0,047 & 0,048 & & 0,004 \\
Nematostella vectensis & 0,051 & 0,059 & 0,059 & 0,057 & \\
\hline
\end{tabular}

Note: Pairwise distances between species are under the diagonal, estimates of standard errors are above the diagonal.

Замечание: Попарные расстояния между видами расположены под основной диагональю, значения стандартных ошибок - над диагональю.

redescribed by Daly (2002). It typically forms dense compact clusters of many specimens. Tentacles of this species have characteristic white lines running along their oral sides. Daly (2002) found unusual long basitrichs in the filaments of E. lineata. We failed to find anything similar in the examined specimens of E. loveni.

The status of fifth nominal species included in the genus, E. janthina (Andres, 1881), described from Mediterranean Sea, is not clear. Williams (1981) transferred Edwardsia janthina Andres, 1881 to Fagesia (junior objective synonym of Edwardsiella). This opinion was based solely on the picture of Andres (1883) where anemone is shown protruding from the hole in rock. Williams (1981) thought it may be synonymous with Edwardsiella carnea.

\section{Results of molecular analysis}

Five gene sequences (mitochondrial 12S rRNA, 16S rRNA, COIII, and nuclear 18S rRNA and 28S rRNA) of Edwardsiella loveni were concatenated to be compared with available sequences of other Edwardsiidae. For evolutionary analysis five concatenated fragments of Edwardsia elegans (EU190726, EU190770, GU473338, AF254376, KJ483087), Edwardsia japonica (GU473274, GU473288, GU473359, GU473304, KJ483048), Edwardsia timida (GU473281, GU473299, KJ482996, GU473315, JF832999) and Nematostella vect- ensis (EU190750, AY169370, FJ489501, AF254382, AY345871) found in the nucleotide database of GenBank were used. Table 5 was obtained using Tamura-Nei model (MEGA 6.0). The estimates of evolutionary divergence show that among the species listed above Edwardsia elegans is the closest species for E. loveni (Pairwise Distance — 0,040, Standard Error 0,004).

One mitochondrial haplotype was detected among two groups of Octineon suecicum clones. Only 16S rRNA fragment of these specimens was well sequenced. The phylogenetc reconstruction based on the 16S rRNA mitochondrial sequences is provided for a number of species (Fig. 9). The topology of resulted unrooted phylograms is identical, thus only one of them is presented in Fig. 9. Different bootstrap values for ME/ML/NJ were calculated and Tamura 3parameter model (MEGA 6.0) was used. A phylogenetic analysis shows that $O$. suecicum groups with the species belonging to Hormathiidae, Actinoscyphiidae, Spongiactinidae, Galatheanthemidae and Bathyphellidae (Fig. 9), but its clade with Actinauge richardi (Marion, 1882) has a weak bootstrap support $(60 / 65 / 61 \%$, respectively). The possible affinity of Octineonidae with Hormathiidae is supported by some features of cnidom and morphology, namely by the presence in both families of acontia with basitrichs only and development of cuticle on the scapus. 


\section{Acknowledgements}

We are grateful to the Swedish Museum of Natural History for loaning type specimens of Octineon suecicum and Dr. A.V. Martynov from Zoological Museum of the Moscow State University who helped to receive these specimens. We also thank Alex English, Douglas Swanston and Geoff Grognet for assistance in field collections and Andy Lamb and Bernard Hanby for additional reports of Edwardsiella loveni in British Columbia. We are grateful Dr. S.D. Grebelnyi and anonymous referee for useful comments and corrections of the manuscript. The work was partially supported by grant of Russian Foundation for Basic Research (RFBR) 16-04-01685 a.

\section{References}

Andres A. 1883. Le attinie. Contenente Bibliografia, Introduzione e Specigrafia. Leipzig: Verlag von Wilhelm Engelmann. 459 p.

Bocharova E.S. 2015. Reproductive biology and genetic diversity of the sea anemone Aulactinia stella (Verrill, 1864) // Hydrobiologia. Vol.759. No.1. P.27-38.

Carlgren O. 1892. Beiträge zur Kenntnis der Edwardsien // Öfversigt af Kongliga Vetenskaps-Akademiens Förhandlingar. Nr.9. S.451-461.

Carlgren O. 1893. Studien über Nordische Actinien I // Kungliga Svenska Vetenskapsakadamiens Handlingar. Bd.25. Nr.10. S.1-148.

Carlgren O. 1921. Actiniaria. Part $1 / /$ The Danish IngolfExpedition. Vol.5. No.1. P.1-241.

Carlgren O. 1931. Zur Kenntnis der Actiniaria Abasilaria // Arkhiv für Zoologie. Bd.23A. Hf.3. S.1-47.

Carlgren O. 1940. A contribution to the knowledge of the structure and distribution of the cnidae in the Anthozoa// Lunds Universitets Årsskrift. N.F. Adv.2. Bd.36. Nr.3. S.1-62.

Carlgren O. 1942. Actiniaria. P.2 // The Danish IngolfExpedition. Vol.5. No.12. P.1-92.

Carlgren O. 1949. A survey of the Ptychodactiaria, Corallimorpharia and Actiniaria // Kungliga Svenska Vetenskapsakademien Handlingar. Bd.1. P.1-129.

Carlgren O. 1959. Corallimorpharia and Actiniaria with description of a new genus and species from Peru // Reports of the Lund University Chile Expedition 1848-49, 38. Lunds Universitets Årsskrift. N.F. Adv.2. Vol.56. No.6. P.1-39.

Daly M. 2002. A systematic revision of Edwardsiidae (Cnidaria, Anthozoa)// Invertebrate Biology. Vol.121. P.212-225.

Fautin D.G. 2016. Hexacorallians of the World. Available from: http:/geoportal.kgs.ku.edu/hexacoral/anemone2/index.cfm

Fowler G.H. 1894. Octineon lindahli (W.B. Carpenter) an undescribed Anthozoan of novel structure // Quarterly Journal of Microscopical Science. Vol.35. No.139. P.461-480.
Geller J.B., Walton D.E. 2001. Breaking up and getting together: evolution of symbiosis and cloning by fission in sea anemones (Genus Anthopleura) // Evolution. Vol.55. P.1781-1794.

Hartog J.C. den. 1995. The genus Telmatactis Gravier, 1916 (Actiniaria: Isophellidae) in Greece and the eastern Mediterranean // Zoologische Mededelingen, Leiden Vol.69. No.14. P.153-176.

Manuel R.L. 1988. British Anthozoa// Synopses of the British Fauna (N.S.). London: Academic Press. No.18. $241 \mathrm{p}$.

Nei M., Kumar S. 2000. Molecular Evolution and Phylogenetics. New York: Oxford University Press, 333 p.

Sanamyan N.P., Sanamyan K.E. 2012. [Isopropanol mineral oil method in histology] // Bugaev F.V., Tokranov A.M., Cherniagina O.A. (eds.). Sokhranenie bioraznoobraziya Kamchatki i prilegayushchikh morei: materialy XIII mezhdunarodnoi nauchnoi konferentsii, posvyashchennoi 75-letiyu so dnya rozhdeniya S.A. Dyrenkova. Petropavlovsk-Kamchatsky: Kamchatpress. P.155-159 [in Russian].

Sanamyan N., Sanamyan K., McDaniel N. 2013. Two new shallow water sea anemones of the family Actiniidae (Cnidaria: Anthozoa: Actiniaria) from British Columbia (NE Pacific) // Invertebrate Zoology. Vol.9. No.2. P.199-216.

Sanamyan N., Sanamyan K., Tabachnick K. 2012. The first species of Actiniaria, Spongiactis japonica gen.n., sp.n. (Cnidaria: Anthozoa) an obligate symbiont of a glass sponge // Invertebrate Zoology. Vol.9. No.2. P.127-141.

Schmidt H. 1969. Die Nesselkapseln der Aktinien und ihre differentialdiagnostische Bedeutung // Helgoländer Wissenschaftliche Meeresuntersuchungen. Vol.19. P.284-317.

Schmidt H. 1972. Die Nesselkapseln der Anthozoen und ihre Bedeutung fur die phylogenetische Systematik // Helgoländer Wissenschaftliche Meeresuntersuchungen. Vol.23. P.422-458.

Schmidt H. 1974. On evolution in the Anthozoa // Proceedings of the Second International Coral Reef Symposium 1. Great Barrier Reef Committee, Brisbane, October, 1974. P.533-560.

Tamura K., Nei M. 1993. Estimation of the number of nucleotide substitutions in the control region of mitochondrial DNA in humans and chimpanzees // Molecular Biology and Evolution. Vol.10. P.512-526.

Tamura K., Stecher G., Peterson D., Filipski A., Kumar S. 2013. MEGA6: Molecular Evolutionary Genetics Analysis Version 6.0 // Molecular Biology and Evolution. Vol.30. P.2725-2729.

Weill R. 1934a. Contribution à l'étude des cnidaires et de leurs nématocystes. I. Recherches sur les nématocystes // Travaux de la station Zoologique de Wimereux. T.10. P.1-347.

Weill R. 1934b. Contribution à l'étude des cnidaires et de leurs nématocystes. II. Valeur taxonomique du cnidome// Travaux de la station Zoologique de Wimereux. T.11. P.349-701.

Williams R.B. 1981. A sea anemone Edwardsia meridionalis sp.n., from Antarctica and a preliminary revision of the genus Edwardsia de Quatrefages, 1841 (Coelenterata: Actiniaria) // Records of the Australian Museum. Vol.33. P.325-360.

Responsible editor A.Yu. Sinev 


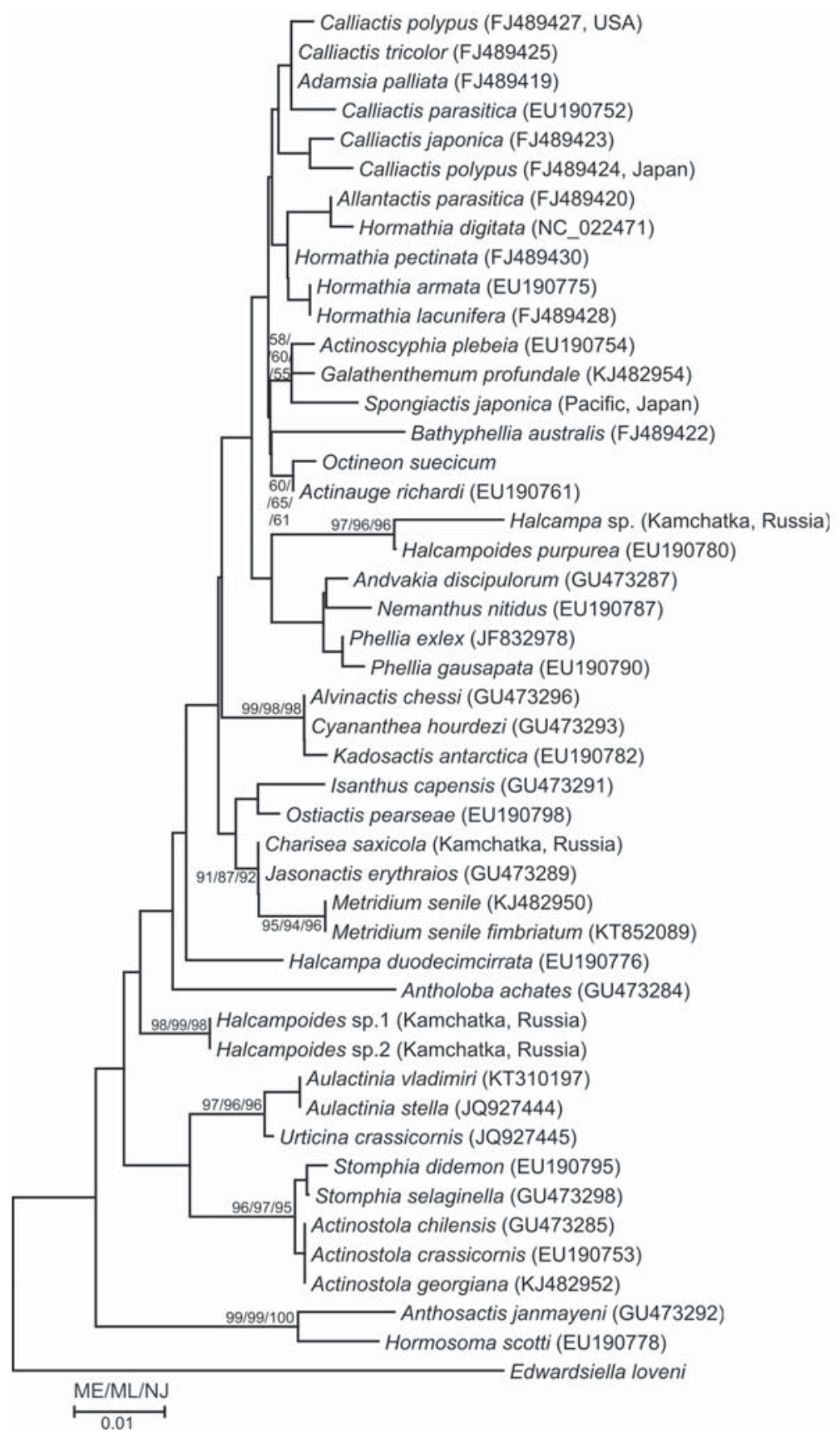

Fig. 9. Tree resulting from Neighbor Joining (NJ) analysis of $16 \mathrm{~S}$ rRNA mitochondrial fragments of Octineon suecicum and Edwardsiella loveni and a number of the species of sea anemones found in the nucleotide database of GenBank. The phylogram was reconstructed by Tamura 3-parameter model (MEGA 6.0). Numbers on nodes represent bootstrap values calculated by Minimum Evolution (ME) method (rates among sites - gamma distributed, No of discrete gamma categories - 1, Close-Neighbor-Interchange heuristic method, Neighbor Joining initial tree, search level — 1, 1000 replicates); Maximum Likelihood 